\title{
OPEN Reference gene selection for qRT-PCR analyses of luffa (Luffa cylindrica) plants under abiotic stress conditions
}

\author{
Min-dong Chen, Bin Wang, Yong-ping Li, Mei-juan Zeng, Jian-ting Liu, Xin-ru Ye, \\ Hai-sheng Zhu $\bowtie$ Q Qing-fang Wen
}

Selecting suitable internal reference genes is an important prerequisite for the application of quantitative real-time PCR (qRT-PCR). However, no systematic studies have been conducted on reference genes in luffa. In this study, seven reference genes were selected, and their expression levels in luffa plants exposed to various simulated abiotic stresses [i.e., cold, drought, heat, salt, $\mathrm{H}_{2} \mathrm{O}_{2}$, and abscisic acid (ABA) treatments] were analyzed by qRT-PCR. The stability of the reference gene expression levels was validated using the geNorm, NormFinder, BestKeeper, and RefFinder algorithms. The results indicated that $E F-1 \alpha$ was the most stably expressed and suitable reference gene overall and for the heat, cold, and ABA treatments. Additionally, UBO expression was stable following the salt treatment, whereas TUB was identified as a suitable reference gene for $\mathrm{H}_{2} \mathrm{O}_{2}$ and drought treatments. The reliability of the selected reference genes was verified by analyzing the expression of copper/zinc superoxide dismutase (Cu/Zn-SOD) gene in luffa. When the most unstable reference genes were used for data normalizations, the resulting expression patterns had obvious biases when compared with the expression patterns for the most ideal reference genes used alone or combined. These results will be conducive to more accurate quantification of gene expression levels in luffa.

Quantitative real-time PCR (qRT-PCR), which is a molecular technique enabling researchers to quantitatively analyze nucleic acids, was developed based on the common PCR technique and has been widely used in many research fields (e.g., agriculture, medicine, microbiology, and molecular diagnostics) ${ }^{1-3}$. The advantages of qRTPCR include its specificity, sensitivity, and reproducibility as well as the fact it can be completed very quickly and efficiently, making it appropriate for assessing gene expression and rapidly quantifying mRNA transcripts ${ }^{4,5}$. However, the accuracy of this quantitative analysis can be influenced by the initial template quantity, the RNA quality, and the enzymatic reaction efficiency ${ }^{6,7}$. Therefore, normalizing target gene expression levels against the data for suitable reference genes is essential for minimizing the biases associated with qRT-PCR results.

Reference genes, also known as housekeeping genes, refer to genes that are generally stably expressed in different tissues and developmental stages as well as under various experimental conditions. Common reference genes include $18 \mathrm{~S}$ ribosomal RNA (18S), $\beta$-tubulin (TUB), a-tubulin (TUA), elongation factor 1 alpha $(E F-1 \alpha)$, ubiquitin $(U B Q)$, glyceraldehyde-3-phosphate dehydrogenase $(G A P D H)$, and actin $(A C T)$ genes ${ }^{8,9}$. However, many studies have confirmed there is a lack of universal reference genes for plants. The suitability of specific reference genes depends on the experimental conditions, and the use of unstably expressed reference genes will likely produce biased results and false-positives ${ }^{10,11}$. Gutierrez et al. ${ }^{12}$ revealed that several genes commonly used as reference controls in Arabidopsis thaliana studies are unstably expressed. Additionally, using non-validated reference genes can lead to 100 -fold changes in target gene expression levels. Therefore, selecting and validating reference genes under diverse experimental conditions is crucial before a meaningful qRT-PCR analysis can be performed. There are currently several publicly available online statistical tools, including geNorm, NormFinder, BestKeeper, and RefFinder, developed to identify a series of appropriate reference genes as internal controls for normalizing qRT-PCR data.

Fujian Key Laboratory of Vegetable Genetics and Breeding, Crops Research Institute, Fujian Academy of Agricultural Sciences, Vegetable Research Center, Fujian Engineering Research Center for Vegetables, Fuzhou 350013, Fujian, China. ${ }^{凶}$ email: zhs0246@163.com; fjvrc@163.com 


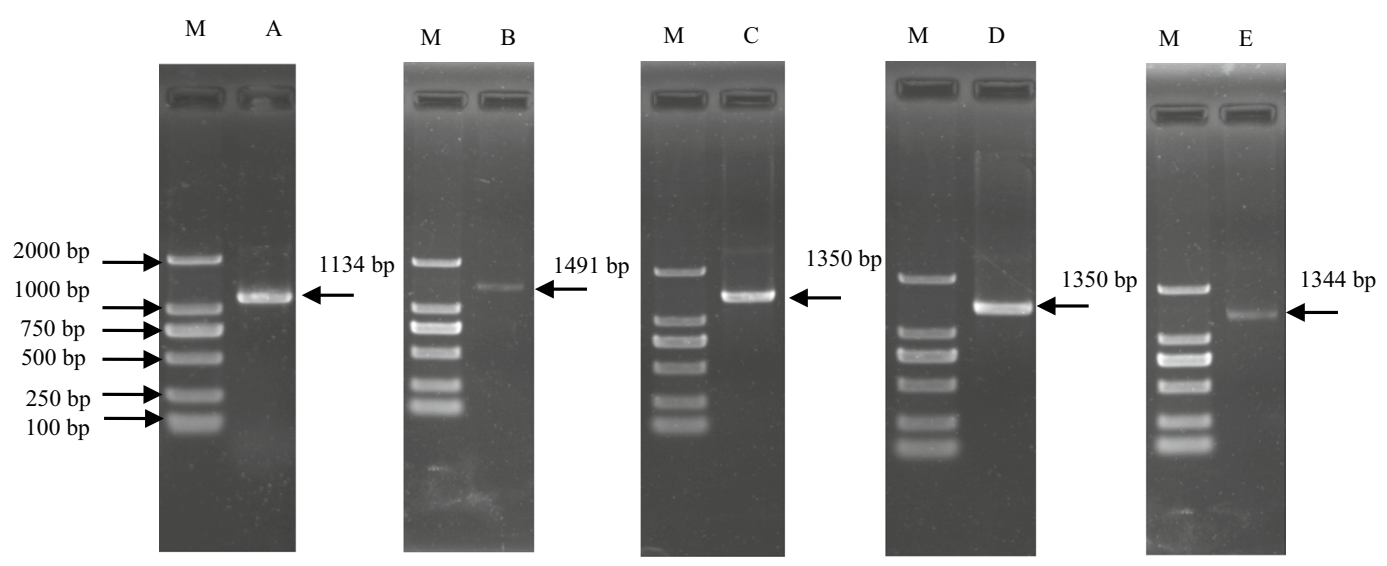

Figure 1. Agarose gel electrophoresis analysis of the ORFs for five reference genes in luffa. M: Marker 2000; A: $A C T$; B: GAPDH; C: TUA; D: TUB; E: EF-1 $\alpha$. The gels were cropped and the full-length gels were presented in Supplementary Fig. 1, 2.

Luffa cylindrica (i.e., luffa), which belongs to the family Cucurbitaceae, is one of the most important vegetables and widely used medicinal plants in China. Many luffa plant parts and components (e.g., mature fruit, leaf, stem, root, seed, flavonoid and polysaccharide) have been used in cough remedies and for treating rhinitis and lumbago. Therefore, there may be a considerable market for luffa products, making the commercial production of luffa an economically important industry ${ }^{13}$. However, the early luffa fruit development stage generally coincides with a period of heavy rainfall and high temperatures, which can damage seedlings (e.g., rotting roots and leaves), leading to considerable decreases in productivity. Plants are exposed to a variety of abiotic and biotic stresses that can restrict growth and development, with abiotic stresses proven to adversely affect crop yield and quality ${ }^{14}$. Consequently, the mechanism regulating the adaptation of luffa to abiotic stresses must be elucidated, including the related genes, which necessitates the selection of suitable reference genes for gene expression analyses. To date, the research regarding reference genes appropriate for luffa has been quite limited (i.e., only $18 S^{15}$ ), and the stability of reference genes has rarely been reported. In the present study, five common reference genes (ACT, TUA, TUB, EF-1 $\alpha$, and GAPDH) were cloned from luffa seedlings. These genes along with two previously cloned reference genes, $U B Q^{16}$ and $18 S$, were analyzed to identify the most reliable reference genes for normalizing target gene expression via qRT-PCR. Experimental samples were exposed to various stresses, including heat, cold, $\mathrm{H}_{2} \mathrm{O}_{2}$, salt, abscisic acid (ABA), and drought. Four algorithms (geNorm, NormFinder, BestKeeper, and RefFinder) were applied to evaluate the reference genes and to identify the most stably expressed genes under diverse conditions. Furthermore, to assess the utility of the validated reference genes, the expression levels of copper/zinc superoxide dismutase $(\mathrm{Cu} / \mathrm{Zn}-\mathrm{SOD})$ gene under the above conditions were examined. The results of these analyses may provide the basis for future qRT-PCR-based investigations of the transcription of important functional genes in luffa.

\section{Results}

Isolation of reference genes. The sequencing results indicated that the full-length ORF sequences of the ACT, TUA, TUB, EF-1 $\alpha$, and GAPDH genes were 1134, 1350, 1350, 1344, and $1491 \mathrm{bp}$ long, respectively (Fig. 1). A BLAST analysis revealed that the ACT amino acid sequence was more than $98 \%$ identical to Cucumis melo (XP_008447829.1), Momordica charantia (XP_022143797.1), and Theobroma cacao (XP_017977121.1) sequences. The TUA amino acid sequence was more than $98 \%$ identical to Momordica charantia (XP_022153822.1), Cucurbita moschata (XP_022944288.1), and Vitis vinifera (XP_002285721.1) sequences. The TUB amino acid sequence was more than 96\% identical to Cucumis sativus (XP_004139067.1), Momordica charantia (XP_022153267.1), and Brassica oleracea (VDD33972.1) sequences. The EF-1a amino acid sequence was more than 96\% identical to Cucurbita moschata (XP_022959419.1), Gossypium hirsutum (XP_012468306.1), and Vitis vinifera (XP_002284924.1) sequences. The GAPDH amino acid sequence was more than $96 \%$ identical to Cucurbita moschata (XP_022937833.1), Cucumis melo (XP_008456541.1), and Momordica charantia (XP_022143215.1) sequences. These sequence matches confirmed that the obtained sequences corresponded to the $A C T, T U A, T U B, E F-1 \alpha$, and GAPDH genes.

Primer specificity and amplification efficiency analysis. Seven genes (ACT, TUA, TUB, EF-1 $\alpha$, $G A P D H, U B Q$, and $18 S$ ) were selected as candidate reference genes. Information regarding these genes and their qRT-PCR primer pairs are summarized in Table 1. Gel electrophoresis and melting curve analyses were used to determine primer specificity. All primers amplified a single amplicon of the expected size (Fig. 2). The seven candidate reference genes under various abiotic stress conditions produced a single peak during the melting curve analysis (Fig. 3). These results indicated the primers for these genes were highly specific. The amplification efficiencies for the seven candidate reference genes ranged from $97.6 \%$ (TUB) to $104.2 \%$ (18S), and the correlation coefficients varied from $0.988(A C T)$ to $0.997(18 S)$ (Table 1). Therefore, all primers were appropriate for qRT-PCR analyses. 


\begin{tabular}{|c|c|c|c|c|c|c|}
\hline Gene & Gene description & Genbank ID & $\begin{array}{l}\text { Primer sequences (forward } \\
\text { primer/reverse primer, } \\
5^{\prime}-3^{\prime} \text { ) }\end{array}$ & Product length (bp) & $\begin{array}{l}\text { Amplification efficiency } \\
(\%)\end{array}$ & Correlation coefficient $R$ \\
\hline$U B Q$ & Polyubiquitin & KR349345 & $\begin{array}{l}5^{\prime} \text {-TGCTTCGTCTCAGGG } \\
\text { GTGG-3' } \\
\text { 5'-GTCCTGAATTTTAGC } \\
\text { TTTCAC-3' }\end{array}$ & 116 & 102.5 & 0.991 \\
\hline$T U B$ & Beta-tubulin & MN548043 & $\begin{array}{l}\text { 5'-GTGCTGGTAATAACT } \\
\text { GGG-3' } \\
\text { 5'-GGGAAGACGGAGAAA } \\
\text { GTA-3' } \\
\end{array}$ & 226 & 97.6 & 0.992 \\
\hline$E F-1 \alpha$ & Elongation factor- $1 \alpha$ & MN548044 & $\begin{array}{l}\text { 5'-TCAAGAAGGTCGGAT } \\
\text { ACA-3' } \\
\text { 5'-ACAGGGACAGTTCCA } \\
\text { ATAC-3' }\end{array}$ & 223 & 97.8 & 0.991 \\
\hline $18 S$ & $18 \mathrm{~S}$ ribosomal RNA & KM656452 & $\begin{array}{l}\text { 5'-CTGGTCTTTTCGGAT } \\
\text { GAT-3' } \\
\text { 5'-CCTTTACGCCCAGTC } \\
\text { ATT-3' }\end{array}$ & 266 & 104.2 & 0.997 \\
\hline GAPDH & $\begin{array}{l}\text { Glyceraldehyde-3-phosphate } \\
\text { dehydrogenase }\end{array}$ & MK766385 & $\begin{array}{l}\text { 5'-TTATCAACCCCACTA } \\
\text { CCA-3' } \\
\text { 5'-TTCCTTCACCAAACA } \\
\text { CTC-3' }\end{array}$ & 203 & 98.6 & 0.995 \\
\hline$A C T$ & Actin & MN548045 & $\begin{array}{l}\text { 5'-GTCGCCCTCGCCATA } \\
\text { CAG-3' } \\
\text { 5'-CTCTTCGGGAGCAAC } \\
\text { ACG-3' }\end{array}$ & 194 & 101.8 & 0.988 \\
\hline TUA & Alpha-tubulin & MK778379 & $\begin{array}{l}\text { 5'-ATTGGACAGGCTGGG } \\
\text { ATT-3' } \\
\text { 5'-TTGGCAGCATCTTCT } \\
\text { TTT-3' }\end{array}$ & 278 & 100.5 & 0.993 \\
\hline$L c C u / Z n-S O D 1$ & $\begin{array}{l}\text { Copper/zinc superoxide } \\
\text { dismutase }\end{array}$ & KP178922 & $\begin{array}{l}\text { 5'-CACAGGAAAGATGGT } \\
\text { GAAGG-3' } \\
\text { 5'-CCAGCAGGGTTGAAA } \\
\text { TGT-3' }\end{array}$ & 210 & & \\
\hline
\end{tabular}

Table 1. Details on primers used for qRT-PCR analysis.

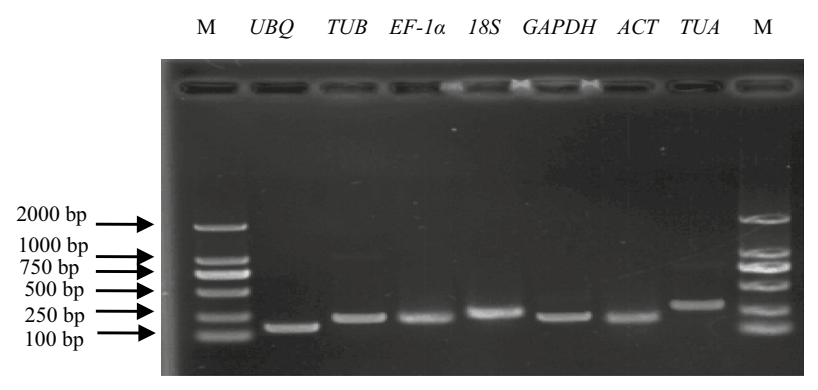

Figure 2. Agarose gel electrophoresis analysis of primer specificity.

Expression profiles of reference genes. The expression levels of the seven reference genes were calculated based on the Ct values (Supplementary Table S1), with lower Ct values corresponding to higher expression levels. Box plots were used to present the distribution of the Ct values (Fig. 4). The average Ct values across all samples varied from 20.13 to 26.25 , reflecting the diversity in expression levels. Five genes ( $U B Q, E F-1 \alpha, 18 S$, $T U A$, and GAPDH) were highly expressed, with average Ct values between 20 and 22, whereas two genes (TUB and $A C T$ ) were moderately expressed, with $\mathrm{Ct}$ values between 24 and 26 . Of all analyzed genes, the highest and lowest expression levels were calculated for $U B Q$ (mean Ct of 20.13) and ACT (mean Ct of 26.25), respectively. Additionally, the most and least variable expression were detected for GAPDH and TUA, respectively, suggesting that GAPDH was the most unstably expressed gene, whereas TUA was the most stably expressed gene.

Expression stability of reference genes. In this study, gene expression was examined in plants exposed to various abiotic stress conditions (i.e., heat, cold, $\mathrm{H}_{2} \mathrm{O}_{2}$, salt, ABA, and drought stresses). Four algorithms (geNorm, NormFinder, BestKeeper, and RefFinder) were used to analyze the expression of relatively stable reference genes.

geNorm analysis. The geNorm algorithm evaluates the stability of reference gene expression by calculating the average $M$ value, with values less than 1.5 indicating stable expression. Thus, the gene with the lowest $M$ value is considered to be the most stably expressed. In this study, the most stably expressed reference gene dif- 

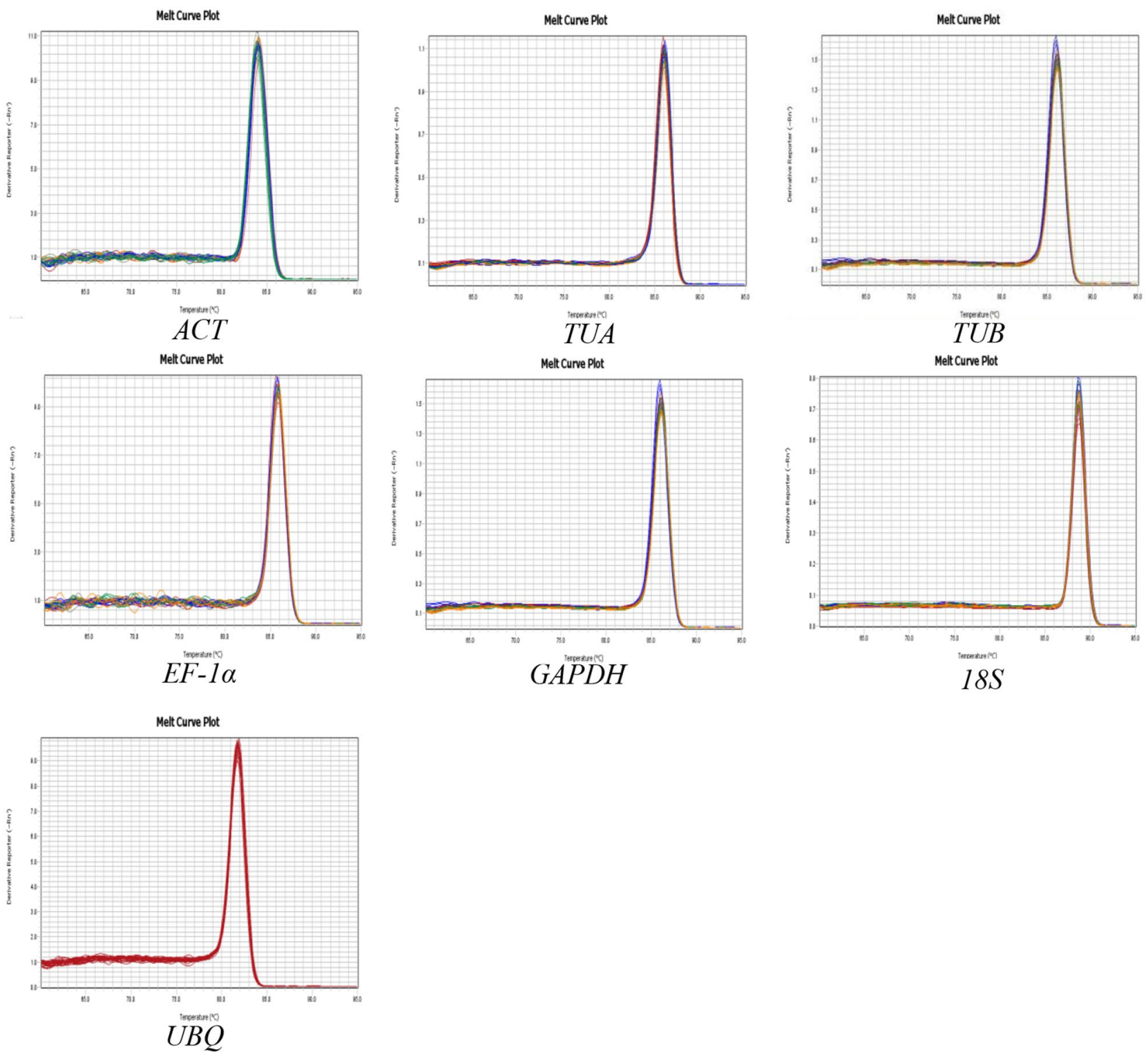

Figure 3. Melting curve analysis of seven reference genes.

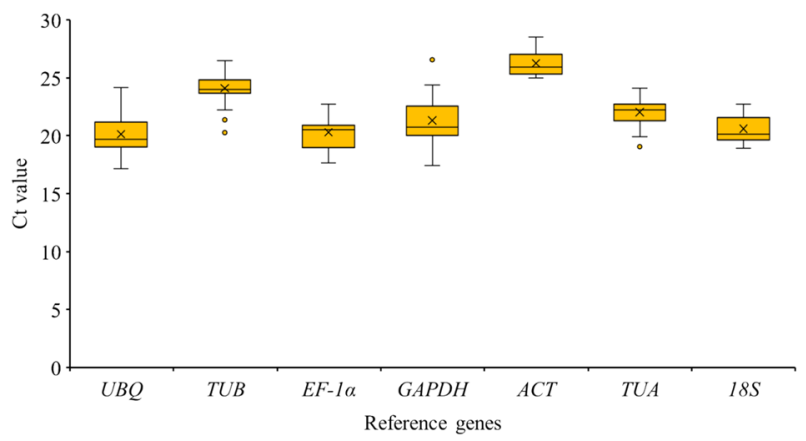

Figure 4. Distribution of Ct values among the seven candidate reference genes across all analyzed luffa samples. The box indicates the 25th and 75th percentiles, with the line across the box representing the median. The whiskers and asterisks represent the $95 \%$ confidence intervals and outliers, respectively. 
Heat stress

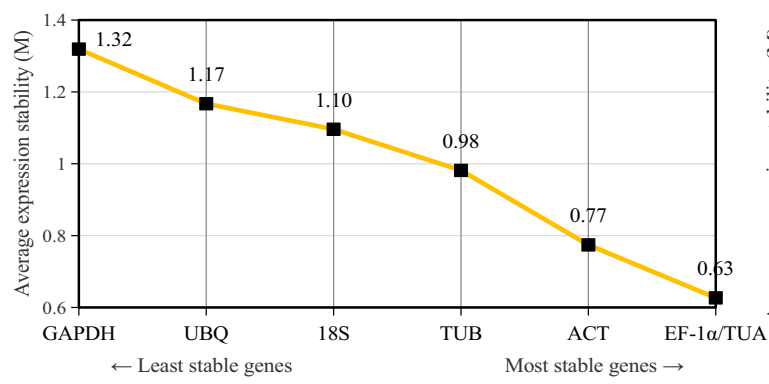

Salt stress

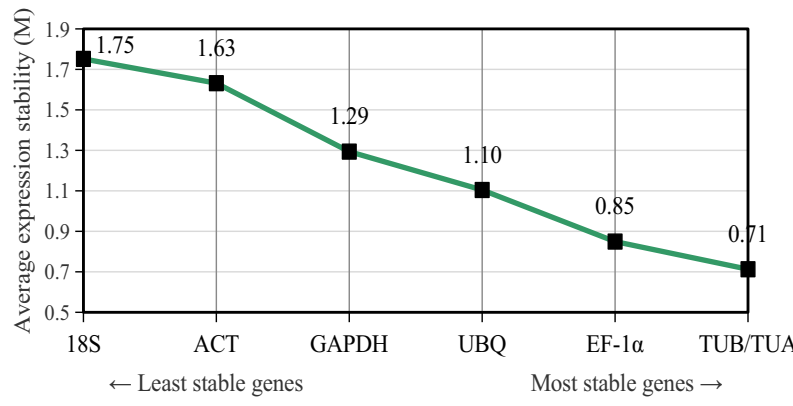

ABA stress

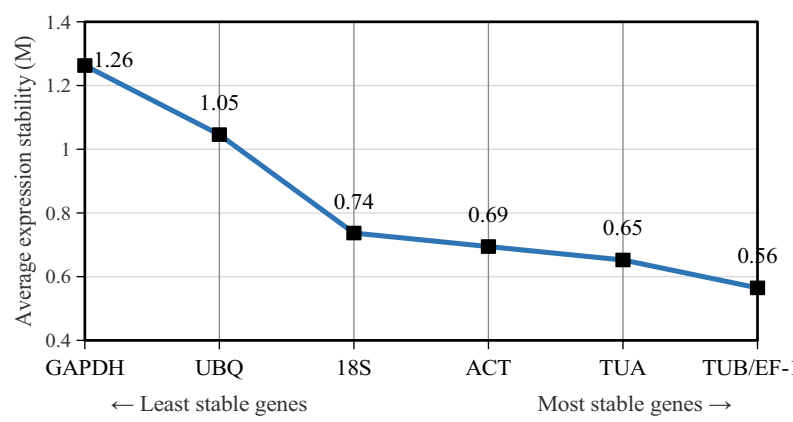

All samples
Cold stress

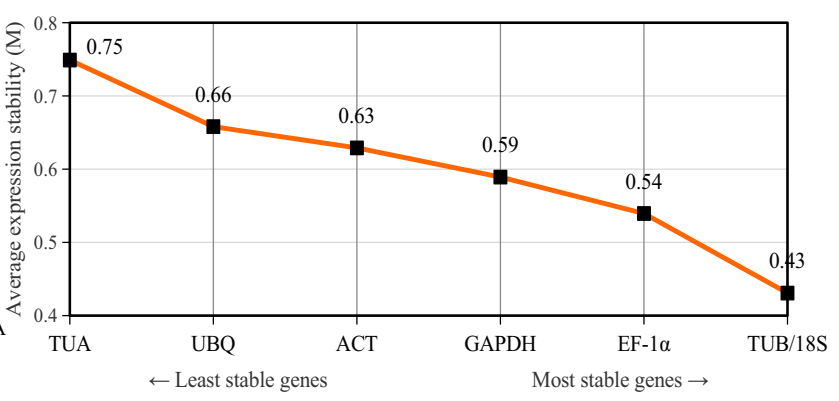

$\mathrm{H}_{2} \mathrm{O}_{2}$ stress

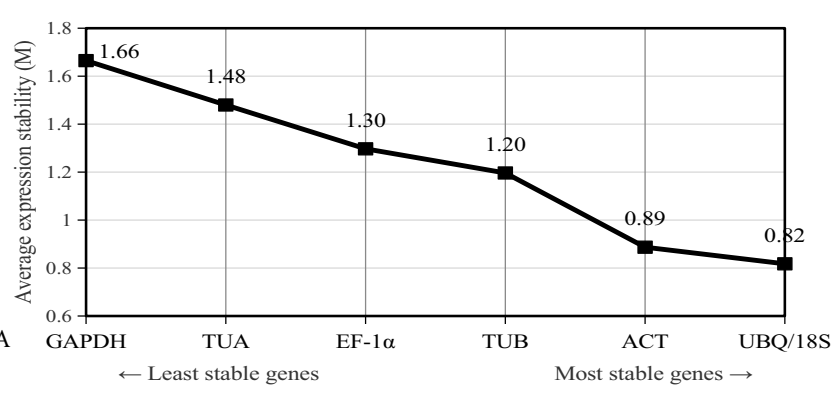

Drought stress

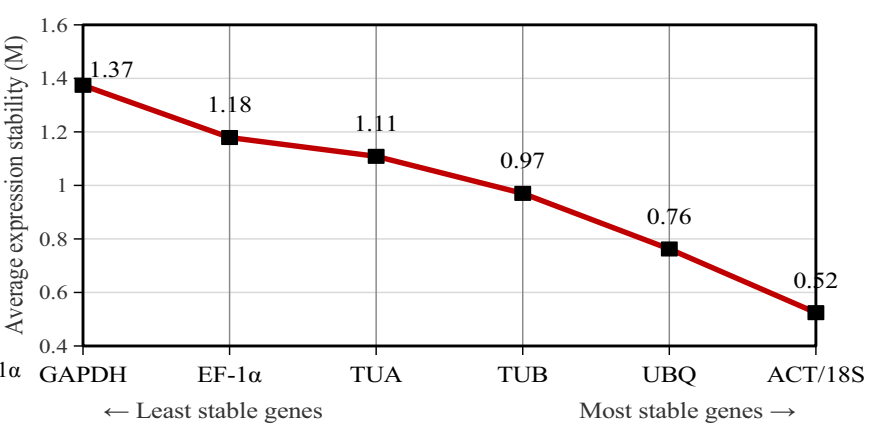

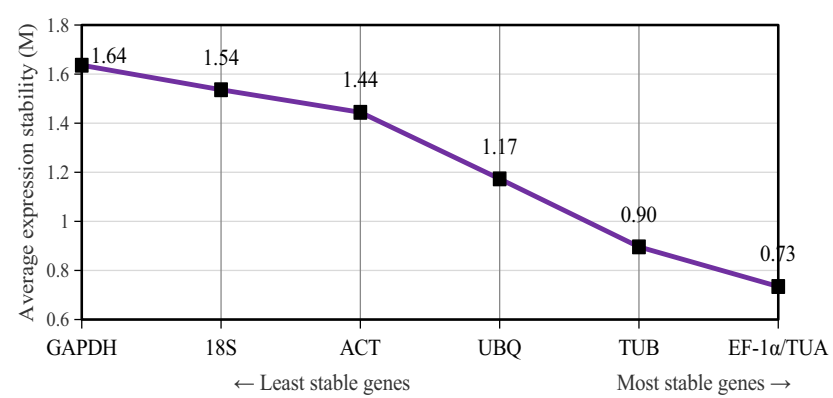

Figure 5. Expression stability of seven reference genes in luffa under different conditions based on a geNorm analysis.

fered among the stress conditions. For the heat treatment, EF-1 $\alpha$ and TUA were the most stably expressed genes, with an $\mathrm{M}$ value of 0.63 , whereas $G A P D H$ was the least stably expressed gene, with an $\mathrm{M}$ value of 1.32 . For the cold treatment, TUB and $18 S(\mathrm{M}=0.43)$ were the most stably expressed genes, whereas $T U A(\mathrm{M}=0.75)$ was the least stably expressed gene. Regarding the $\mathrm{H}_{2} \mathrm{O}_{2}$ treatment, the most stably expressed genes were $U B Q$ and $18 S$ $(\mathrm{M}=0.82)$ and the least stably expressed gene was $G A P D H(\mathrm{M}=1.66)$. In response to the salt treatment, TUB and TUA $(\mathrm{M}=0.71)$ had the most stable expression levels, whereas $18 S(\mathrm{M}=1.75)$ had the most unstable expression level. For the ABA treatment, $E F-1 \alpha$ and TUB $(\mathrm{M}=0.56)$ were detected as the most stably expressed genes and GAPDH $(\mathrm{M}=1.26)$ was identified as the most variably expressed gene. Following the drought treatment, the expression levels were most stable for ACT and $18 S(\mathrm{M}=0.52)$ and least stable for GAPDH $(\mathrm{M}=1.37)$. Overall, $E F-1 \alpha$ and TUA $(\mathrm{M}=0.73)$ were the most stably expressed genes in all samples, whereas $G A P D H(\mathrm{M}=1.64)$ was the least stably expressed gene (Fig. 5). 


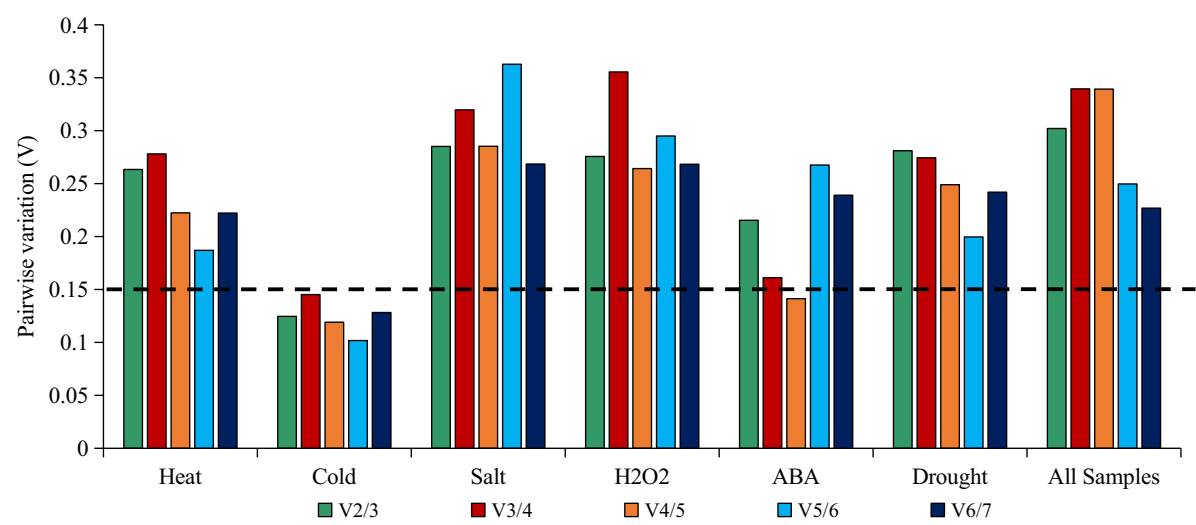

Figure 6. geNorm analysis of the $\mathrm{V}$ values for the seven reference genes under various conditions.

\begin{tabular}{|c|c|c|c|c|c|c|c|c|}
\hline \multirow[b]{2}{*}{ Rank } & \multicolumn{2}{|l|}{ Heat } & \multicolumn{2}{|l|}{ Cold } & \multicolumn{2}{|l|}{ Salt } & \multicolumn{2}{|l|}{$\mathrm{H}_{2} \mathrm{O}_{2}$} \\
\hline & Gene & SV & Gene & SV & Gene & SV & Gene & SV \\
\hline 1 & $E F-1 \alpha$ & 0.595 & $E F-1 \alpha$ & 0.243 & $U B Q$ & 0.454 & $T U B$ & 0.470 \\
\hline 2 & $18 S$ & 0.716 & $T U B$ & 0.418 & $T U A$ & 0.822 & $E F-1 \alpha$ & 0.801 \\
\hline 3 & $A C T$ & 0.858 & $18 S$ & 0.420 & $E F-1 \alpha$ & 1.034 & $U B Q$ & 0.906 \\
\hline 4 & TUA & 0.860 & GAPDH & 0.451 & TUB & 1.365 & $A C T$ & 0.909 \\
\hline 5 & $U B Q$ & 0.892 & $A C T$ & 0.522 & GAPDH & 1.482 & $18 S$ & 1.542 \\
\hline 6 & $T U B$ & 1.127 & $U B Q$ & 0.698 & $A C T$ & 1.745 & TUA & 1.728 \\
\hline \multirow[t]{2}{*}{7} & GAPDH & 1.508 & TUA & 0.876 & $18 S$ & 1.811 & GAPDH & 1.862 \\
\hline & \multicolumn{2}{|l|}{ ABA } & \multicolumn{2}{|l|}{ Drought } & \multicolumn{2}{|c|}{ All samples } & & \\
\hline Rank & Gene & SV & Gene & SV & Gene & SV & & \\
\hline 1 & $E F-1 \alpha$ & 0.282 & TUB & 0.438 & $E F-1 \alpha$ & 0.829 & & \\
\hline 2 & TUA & 0.289 & $18 S$ & 0.726 & $T U B$ & 0.877 & & \\
\hline 3 & $T U B$ & 0.500 & $U B Q$ & 0.743 & TUA & 1.055 & & \\
\hline 4 & $A C T$ & 0.726 & $A C T$ & 1.000 & $U B Q$ & 1.121 & & \\
\hline 5 & $18 \mathrm{~S}$ & 1.019 & TUA & 1.076 & $A C T$ & 1.331 & & \\
\hline 6 & $U B Q$ & 1.451 & $E F-1 \alpha$ & 1.145 & $18 S$ & 1.432 & & \\
\hline 7 & GAPDH & 1.640 & GAPDH & 1.654 & GAPDH & 1.519 & & \\
\hline
\end{tabular}

Table 2. Expression stability of seven reference genes following various treatments based on a NormFinder analysis.

For optimal data normalization, two or more reference genes are necessary for qRT-PCR analyses. The optimal number of reference genes can be determined with the geNorm algorithm, which calculates the pairwise variation $V_{n} / V_{n+1}$. If $V_{n} / V_{n+1}$ is less than $0.15, n$ is the most suitable number of internal reference genes. However, if $\mathrm{V}_{\mathrm{n}} / \mathrm{V}_{\mathrm{n}+1}$ is greater than $0.15, \mathrm{n}+1$ is the ideal number of internal reference genes. For the cold treatment, $\mathrm{V}_{2} /$ $\mathrm{V}_{3}$ was less than 0.15 (Fig. 6), implying that two reference genes are sufficient for normalizing gene expression data. Regarding the $\mathrm{ABA}$ treatment, $\mathrm{V}_{4} / \mathrm{V}_{5}$ was less than 0.15 , indicating that four reference genes should be used for the data normalization. For the other four treatments, $V_{n} / V_{n+1}$ exceeded 0.15 , and the optimal number of reference genes was not determined.

NormFinder analysis. NormFinder calculates the SV for each reference gene based on the intragroup and intergroup variations. Lower SVs correspond to higher gene expression stability. For the heat and ABA treatments as well as overall (i.e., all treatments), EF- $1 \alpha$ and GAPDH were the most and least stably expressed reference genes, respectively. For the cold treatment, $E F-1 \alpha$ was the most stably expressed reference gene, whereas TUA was the least stably expressed reference gene. Regarding the $\mathrm{H}_{2} \mathrm{O}_{2}$ and drought treatments, TUB and $G A P D H$ were the most and least stably expressed reference genes, respectively. In response to the salt treatment, the most and least stably expressed genes were $U B Q$ and $18 S$, respectively (Table 2).

BestKeeper analysis. BestKeeper calculates the stability of candidate reference genes based on the SD, r, and $\mathrm{CV}$ of the $\mathrm{Ct}$ data for all reference genes. Low SD and CV values reflect stable gene expression. The rankings based on the BestKeeper analysis revealed that four reference genes were stably expressed following the heat treatment, of which $A C T(\mathrm{CV} \pm \mathrm{SD}=0.59 \pm 0.149)$ was the most stably expressed. For the cold treatment, all seven ref- 


\begin{tabular}{|c|c|c|c|c|c|c|c|c|c|c|c|c|}
\hline \multirow[b]{2}{*}{ Rank } & \multicolumn{3}{|l|}{ Heat } & \multicolumn{3}{|l|}{ Cold } & \multicolumn{3}{|l|}{ Salt } & \multicolumn{3}{|l|}{$\mathrm{H}_{2} \mathrm{O}_{2}$} \\
\hline & Gene & SD & $\mathrm{CV}$ & Gene & SD & $\mathrm{CV}$ & Gene & SD & $\mathrm{CV}$ & Gene & SD & CV \\
\hline 1 & $A C T$ & 0.149 & 0.59 & $A C T$ & 0.298 & 1.16 & $U B Q$ & 0.56 & 2.98 & TUB & 0.494 & 2.13 \\
\hline 2 & TUA & \begin{tabular}{|l|}
0.727 \\
\end{tabular} & 3.38 & $E F-1 \alpha$ & 0.342 & 1.63 & $18 \mathrm{~S}$ & 0.883 & 4.31 & $E F-1 \alpha$ & 0.513 & 2.7 \\
\hline 3 & $T U B$ & 0.746 & 3.08 & $18 S$ & 0.443 & 2.23 & $A C T$ & 0.932 & 3.51 & $A C T$ & 0.606 & 2.25 \\
\hline 4 & $E F-1 \alpha$ & 0.747 & 3.75 & GAPDH & 0.458 & 2.17 & TUA & 0.998 & 4.6 & $U B Q$ & 0.777 & 3.99 \\
\hline 5 & $18 S$ & 1.008 & 4.91 & TUA & 0.475 & 2.1 & $E F-1 \alpha$ & 1.144 & 5.72 & TUA & 1.055 & 5.09 \\
\hline 6 & $U B Q$ & 1.325 & 6.66 & TUB & 0.495 & 2 & GAPDH & 1.288 & 6.23 & $18 S$ & 1.271 & 5.88 \\
\hline \multirow[t]{2}{*}{7} & GAPDH & 1.776 & 8.21 & $U B Q$ & \begin{tabular}{|l|}
0.657 \\
\end{tabular} & 3.24 & TUB & 1.534 & 6.71 & GAPDH & 1.288 & 6.39 \\
\hline & \multicolumn{3}{|l|}{ ABA } & \multicolumn{3}{|l|}{ Drought } & \multicolumn{3}{|c|}{ All samples } & & & \\
\hline Rank & Gene & SD & CV & Gene & SD & CV & Gene & SD & $\mathrm{CV}$ & & & \\
\hline 1 & $T U A$ & 0.44 & 1.9 & $T U B$ & 0.553 & 2.25 & $A C T$ & \begin{tabular}{|l|}
0.875 \\
\end{tabular} & 3.33 & & & \\
\hline 2 & $A C T$ & 0.484 & 1.87 & TUA & 0.554 & 2.46 & $E F-1 \alpha$ & 0.957 & 4.71 & & & \\
\hline 3 & $E F-1 \alpha$ & 0.617 & 2.9 & $E F-1 \alpha$ & 0.794 & 3.84 & TUA & 0.958 & 4.34 & & & \\
\hline 4 & $18 \mathrm{~S}$ & 0.67 & 3.3 & $A C T$ & 0.963 & 3.54 & TUB & 0.973 & 4.04 & & & \\
\hline 5 & TUB & 0.834 & 3.34 & $18 \mathrm{~S}$ & 0.966 & 4.63 & $18 \mathrm{~S}$ & \begin{tabular}{|l|}
1.015 \\
\end{tabular} & 4.92 & & & \\
\hline 6 & GAPDH & 1.335 & 6.22 & $U B Q$ & 1.062 & 5.25 & $U B Q$ & \begin{tabular}{|l|}
1.275 \\
\end{tabular} & 6.34 & & & \\
\hline 7 & $U B Q$ & 1.604 & \begin{tabular}{|l|l|}
7.27 \\
\end{tabular} & GAPDH & 1.34 & 5.87 & GAPDH & \begin{tabular}{|l|}
1.443 \\
\end{tabular} & 6.77 & & & \\
\hline
\end{tabular}

Table 3. Expression stability of seven reference genes following various treatments based on a BestKeeper analysis.

\begin{tabular}{|l|l|l|l|l|l|l|l|}
\hline \multirow{2}{*}{ Rank } & \multicolumn{6}{|l}{ Gene (Geomean of ranking values) } \\
\cline { 2 - 8 } & Heat & Cold & Salt & $\mathbf{H}_{2} \mathbf{O}_{2}$ & ABA & Drought & All samples \\
\hline 1 & $E F-1 \alpha(1.41)$ & $E F-1 \alpha(1.57)$ & $U B Q(1.41)$ & $T U B(1.41)$ & $E F-1 \alpha(1.32)$ & $T U B(1.41)$ & $E F-1 \alpha(1.19)$ \\
\hline 2 & $A C T(2.28)$ & $T U B(2.21)$ & $T U A(2.00)$ & $U B Q(2.45)$ & $T U A(1.86)$ & $18 S(2.11)$ & $T U A(2.28)$ \\
\hline 3 & $T U A(2.38)$ & $18 S(2.28)$ & $T U B(3.25)$ & $E F-1 \alpha(2.51)$ & $T U B(2.59)$ & $A C T(2.83)$ & $T U B(2.63)$ \\
\hline 4 & $18 S(3.16)$ & $A C T(3.34)$ & $E F-1 \alpha(3.41)$ & $A C T(3.46)$ & $A C T(3.36)$ & $U B Q(3.57)$ & $A C T(3.34)$ \\
\hline 5 & $T U B(4.56)$ & $G A P D H(4.00)$ & $A C T(5.05)$ & $18 S(3.50)$ & $18 S(4.73)$ & $T U A(3.98)$ & $U B Q(4.43)$ \\
\hline 6 & $U B Q(5.48)$ & $U B Q(6.24)$ & $18 S(5.12)$ & $T U A(5.73)$ & $U B Q(6.24)$ & $E F-1 \alpha(5.05)$ & $18 S(5.73)$ \\
\hline 7 & $G A P D H(7.00)$ & $T U A(6.44)$ & $G A P D H(5.23)$ & $G A P D H(7.00)$ & $G A P D H(6.74)$ & $G A P D H(7.00)$ & $G A P D H(7.00)$ \\
\hline
\end{tabular}

Table 4. Comprehensive ranking of stability.

erence genes were stably expressed, but $A C T(C V \pm S D=1.16 \pm 0.298)$ and $E F-1 \alpha(C V \pm S D=1.63 \pm 0.342)$ were the most stably expressed. Regarding the salt treatment, the expression of four reference genes was stable, with $U B Q(C V \pm S D=2.98 \pm 0.56)$ identified as the most stably expressed gene. For the $\mathrm{H}_{2} \mathrm{O}_{2}$ treatment, four reference genes were suitable for normalizing gene expression data, among which $T U B(C V \pm S D=2.13 \pm 0.494)$ and $E F-1 \alpha(\mathrm{CV} \pm \mathrm{SD}=2.7 \pm 0.513)$ were the most stably expressed. In response to the $\mathrm{ABA}$ treatment, five reference genes were stably expressed, with $T U A(C V \pm S D=1.9 \pm 0.44)$ and $A C T(C V \pm S D=1.87 \pm 0.484)$ detected as the most stably expressed genes. Following the drought treatment, the expression levels of five reference genes were considerably stable, with $T U B(\mathrm{CV} \pm \mathrm{SD}=2.25 \pm 0.553)$ and $T U A(\mathrm{CV} \pm \mathrm{SD}=2.46 \pm 0.554)$ revealed as the most stably expressed genes. An analysis of all treatments indicated that four reference genes were stably expressed, with $A C T(C V \pm S D=3.33 \pm 0.875)$ identified as the gene with the most stable expression level (Table 3$)$.

RefFinder analysis. Finally, RefFinder was used for the comprehensive ranking of the reference genes under each stress condition. The results indicated that $E F-1 \alpha$ was the most stably expressed gene overall and for the heat, cold, and ABA treatments. The UBQ gene had the most stable expression level following the salt treatment, whereas TUB was the most stably expressed gene in response to the $\mathrm{H}_{2} \mathrm{O}_{2}$ and drought treatments. In contrast, GAPDH was the least stably expressed gene overall and for the heat, salt, $\mathrm{H}_{2} \mathrm{O}_{2}, \mathrm{ABA}$, and drought treatments. Regarding the cold treatment, TUA was the least stably expressed gene (Table 4).

\section{Reference gene validation}

To validate the accuracy of the analysis of reference gene expression stability, the relative expression levels of luffa $\mathrm{LcCu} / \mathrm{Zn}$-SOD1 gene were analyzed under various stresses conditions. The two most stable reference genes and one unstable reference gene according to RefFinder were selected for normalizing gene expression data. The results indicated that when the most ideal reference genes were used alone or combined as the internal reference control, the expression of the $\mathrm{LcCu} / \mathrm{Zn}$-SOD1 exhibited similar trends with minor changes. Moreover, the 

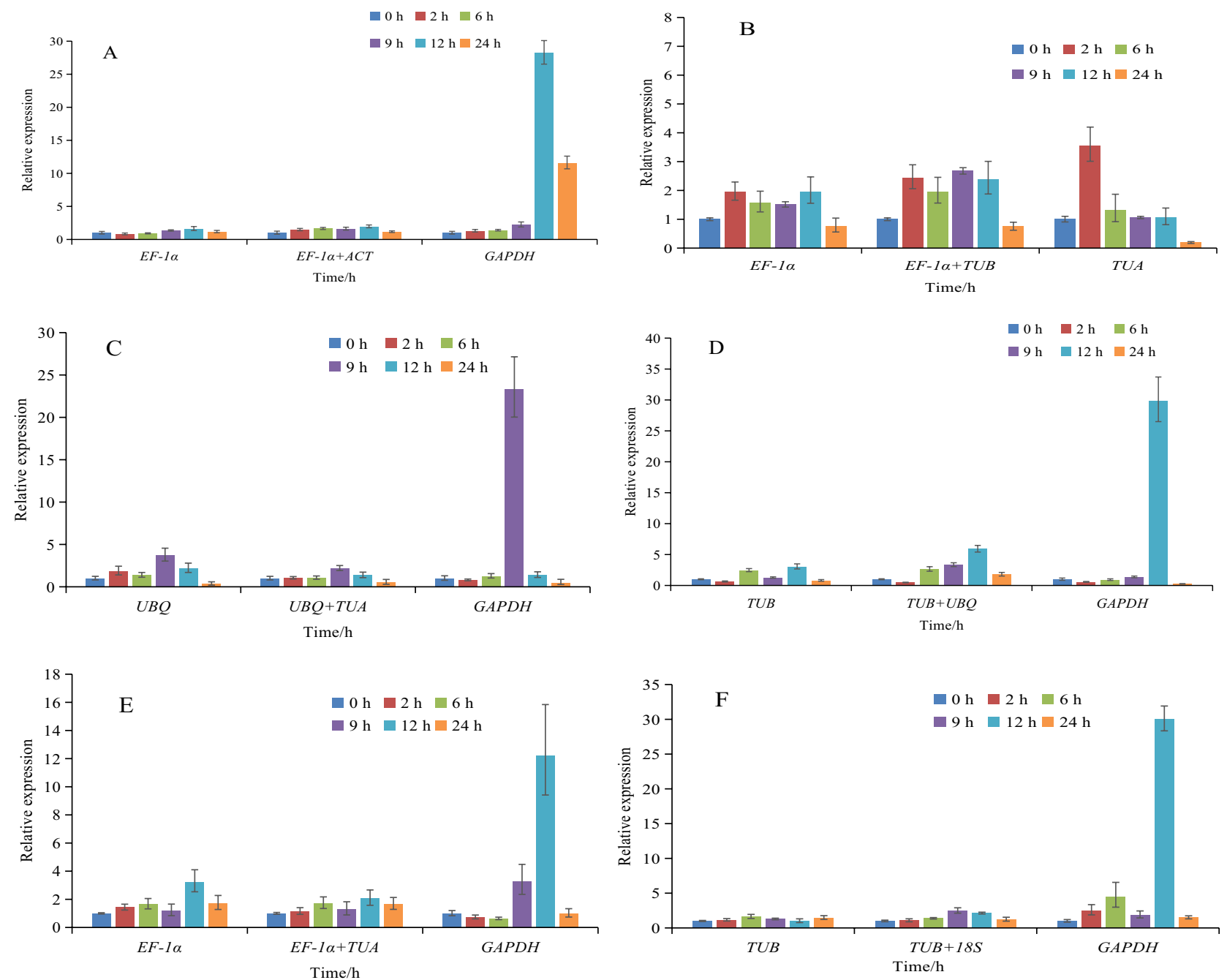

Figure 7. Expression of $L c C u / Z n-S O D 1$ gene under different stresses using validated reference genes for data normalization. (A) Expression of $L c C u / Z n$-SOD1 gene under heat stress using validated reference genes $A C T$ , $E F-1 \alpha$, and $G A P D H$. (B) Expression of $L c C u / Z n$-SOD1 gene under cold stress using validated reference genes $T U A, E F-1 \alpha$, and TUB. (C) Expression of $L c C u / Z n$-SOD1 gene under salt stress using validated reference genes $T U A, U B Q$, and GAPDH. (D) Expression of $L c C u / Z n$-SOD1 gene under $\mathrm{H}_{2} \mathrm{O}_{2}$ stress using validated reference genes TUB, UBQ, and GAPDH. (E) Expression of $L c C u / Z n$-SOD1 gene under ABA stress using validated reference genes TUA, EF-1 $\alpha$, and GAPDH. (F) Expression of $L c C u / Z n-S O D 1$ gene under drought stress using validated reference genes $T U B, 18 S$, and $G A P D H$.

use of two reference genes generally improved the quantification of $L c C u / Z n-S O D 1$ gene expression. However, the $L c C u / Z n-S O D 1$ gene expression patterns were considerably different when the unstable reference gene was used to normalize data. Specifically, the expression levels were significantly higher at 9 or $12 \mathrm{~h}$ under heat, salt, $\mathrm{H}_{2} \mathrm{O}_{2}$, ABA and drought treatment conditions, reflecting the overestimation of gene expression levels at these two time-points (Fig. 7). Therefore, the use of inappropriate reference genes may lead to biased and incorrect expression analyses.

\section{Discussion}

The qRT-PCR assay, which has been widely used for quantifying target gene transcription levels, is an important research tool applicable for characterizing gene functions $s^{17,18}$. However, the accuracy of gene expression analyses mainly depends on the selection of an appropriate internal control, which is often referred to as a reference or housekeeping gene. Reference genes were initially selected primarily based on housekeeping gene functions. For example, $A C T$ and $T U B$ genes encode the basic components of the cytoskeleton, whereas the proteins encoded by $G A P D H, E F-1 \alpha$, and $U B Q$ genes contribute to the basic metabolic processes of organisms. Accordingly, these genes were expected to be stably expressed in all cells and physiological states ${ }^{2}$. Subsequent research proved that reference gene expression levels may vary in different tissues or growth and development stages. The expression might also be influenced by biotic and abiotic stresses and hormones. Thus, there are no internal reference genes that are stably expressed under all experimental conditions ${ }^{19-22}$. For example, GAPDH expression is highly stable in grape berries, but is relatively unstable in wheat ${ }^{23,24}$. Both $A C T$ and $U B Q$ are stably expressed in wheat, but not in tomato ${ }^{24,25}$. Gong et al. ${ }^{26}$ analyzed the expression stability of 18 candidate reference genes of Goji at 
different developmental stages and under drought stress condition. They observed that two novel reference genes LbCML38 and LbRH52 were more stably expressed than the commonly used reference genes. Liu et al. ${ }^{27}$ analyzed perennial ryegrass under high-temperature stress and identified HIS 3 and $e I F 4 A$ as the most suitable reference genes. In another study, $E F-1 \alpha$ and $U B Q$ were detected as the most stable internal reference genes in potato and Arabis alpina under drought conditions ${ }^{28,29}$. Therefore, verifying the expression stability of reference genes under different experimental conditions is critical when selecting reference genes to standardize gene expression levels. However, there has been relatively little research regarding the systematic validation of reference genes in luffa. Only $18 S$ has been reported as a reference gene in luffa, but it has often been used without any proper verification, possibly resulting in inaccurate analyses of luffa gene expression patterns.

In this study, the expression stability of seven candidate reference genes ( $A C T, T U A, T U B, E F-1 \alpha, G A P D H$, $U B Q$, and $18 S$ ) after heat, cold, salt, $\mathrm{H}_{2} \mathrm{O}_{2}, \mathrm{ABA}$, and drought treatments was analyzed with BestKeeper, geNorm, NormFinder, and RefFinder. The objective of this study was to identify the most stable reference genes for investigating gene expression in luffa plants exposed to abiotic stress factors. The data revealed EF-1 $\alpha$ as the most stably expressed gene following the heat, cold, and ABA treatments. This gene, which encodes a polyribosomal protein, is widely expressed in various cells. In many studies on Cucurbitaceae species, $E F-1 \alpha$ has been used as an appropriate reference gene. In cucumber, $E F-1 \alpha, F b o x, C A C$, and TIP41 are reportedly stably expressed regardless of the abiotic stress, growth regulator treatment, and nitrogen status ${ }^{30,31}$. In another study on cucumber, $E F-1 \alpha$ was confirmed as the most stably expressed reference gene ${ }^{32}$. In an earlier study on zucchini, UFP, $E F-1 \alpha, R P L 36 a A, P P 2 A$, and CAC were identified as the ideal reference genes for normalizing expression data ${ }^{33}$. Ye et al. ${ }^{34}$ screened and evaluated reference genes for fluorescence-based real-time quantitative PCR analyses of wax gourd and confirmed that $E F-1 \alpha$ is the most stably expressed reference gene under cold conditions and in different tissues. In the current study, $U B Q$ was the most stably expressed reference gene following the salt treatment, which is consistent with the results of an earlier study by Jin et al..$^{35}$. The UBQ gene belongs to the ubiquitin gene family, which affects many important biological processes, including cell cycle regulation, growth and apoptosis, signal transduction, and immune responses. Because of its high sequence homology and the fact it is highly conserved, $U B Q$ has been used as a reference gene for rice ${ }^{36}$, black fungus ${ }^{37}$, and cucumber ${ }^{32}$. Our data also indicated that TUB was the most stably expressed reference gene for the $\mathrm{H}_{2} \mathrm{O}_{2}$ and drought treatments. This gene is involved in plant growth and development, with an important role in maintaining cell morphology, promoting intracellular transport, and mediating cell movement and cell division, and has often been used as a reference gene. Kiarash et al. ${ }^{38}$ determined that TUB is the most appropriate reference gene for wheat plants under drought conditions. Although $A C T$ is the most commonly used reference gene for cucurbit crops ${ }^{39-41}$, it was not identified as the best reference gene for any of the conditions analyzed in this study. Furthermore, ACT expression reportedly varies substantially in many other crops ${ }^{42}$. Kong et al. ${ }^{20}$ suggested that $A C T$ should be used together with other reference genes for qRT-PCR analyses of melons. In the current study, except for the cold treatment, GAPDH was the most unstably expressed reference gene, implying that GAPDH is not a suitable reference gene for investigations of the effects of abiotic stresses on luffa gene expression. This is consistent with the results of studies by Liu et al. ${ }^{27}$ and Yu et al. ${ }^{43}$. Although GAPDH is the most unsuitable reference gene for annual ryegrass and ramie under different stress conditions, it is ideal for studies of Juglans regia $\mathrm{L}^{44}$, L. speciosa ${ }^{45}$ and Stipa grandis ${ }^{46}$. Therefore, potential internal reference genes must be evaluated and confirmed as appropriate for different experimental systems and materials before they are used to analyze gene expression.

To verify the reliability of the identified reference genes, we analyzed the expression of luffa $L c C u / Z n-S O D 1$ gene. Because of its protective effects on cell membranes, $\mathrm{Cu} / \mathrm{Zn}$-SOD can protect plants from oxidative damage due to reactive oxygen species, while also contributing to plant responses to various abiotic stresses ${ }^{47}$. In the present study, the expression of $L c C u / Z n$-SOD1 gene initially increased in response to the abiotic stress, after which it decreased. This expression pattern was consistent with previously reported stress-induced expression trends $^{48-50}$. Earlier studies tended to emphasize the use of a single reference gene for calibrating the expression of target genes. However, a single reference gene may be unstably expressed under different experimental conditions. Thus, applying multiple genes may increase the accuracy and reliability of data normalizations to some extent ${ }^{51}$. In this study, the combined use of two stably expressed reference genes generally enhanced the quantification of $\mathrm{Cu} / \mathrm{Zn}$-SOD gene expression when compared with the data obtained with a single reference gene. Deng et al. ${ }^{22}$ suggested that potential interactions between reference genes should be examined when using multiple reference genes. A positive or negative relationship between the expression of the reference genes may affect the analysis of the target gene expression level. Reference genes with linearly additive expression may be used together as internal reference controls to improve the normalization of expression data under various experimental conditions. Therefore, the method used to select multiple reference genes should be carefully considered to ensure appropriate combinations are applied.

\section{Methods}

Plant materials and treatments. 'Minyan No. 1', a commercial $\mathrm{F}_{1}$ luffa hybrid, was used in the present study. The seeds were first wrapped with wet gauze and then germinated in an incubator at $30^{\circ} \mathrm{C}$. The seedlings were sown in $10 \times 8 \mathrm{~cm}$ pots containing soil and cultivated in an artificial climate incubator with a 16-h artificial light $\left(25^{\circ} \mathrm{C}\right): 8$-h dark $\left(18{ }^{\circ} \mathrm{C}\right)$ cycle and $65-75 \%$ relative humidity. Seedlings at the third true leaf stage were used for the following treatments. For the heat and cold treatments, the seedlings were incubated at $40^{\circ} \mathrm{C}$ and $4{ }^{\circ} \mathrm{C}$, respectively, for $24 \mathrm{~h}$. For the $\mathrm{ABA}$ and $\mathrm{H}_{2} \mathrm{O}_{2}$ treatments, the seedlings were sprayed with $200 \mu \mathrm{M}$ ABA and $100 \mu \mathrm{M} \mathrm{H}_{2} \mathrm{O}_{2}$, respectively. Regarding the salt and drought stress treatments, the seedlings were transplanted into full-strength Hoagland's nutrient solution containing $100 \mathrm{mM} \mathrm{NaCl}$ or $15 \%$ PEG 6000, respectively, for $24 \mathrm{~h}$. Leaves were then collected at $0,2,6,9,12$, and $24 \mathrm{~h}$ after the treatments. Each experiment was completed 


\begin{tabular}{|c|c|c|}
\hline Gene & Forw & Rever \\
\hline TUB & 5'-ACCGTGAGAAGATGAGGGAA-3' & 5'-GTTACTAATTGTCGAGGTCC-3' \\
\hline$E F-1 \alpha$ & & 5'-AAATGCAGGCTTGGCTGGTT-3' \\
\hline GAPDI & СТTCTTT-3' & GGTGTAGG-3’ \\
\hline ACT & 5'-CTTCGAGCCAAATCGCTTTC-3' & 5'-TCTCAGGTAAAACCGTACCG-3' \\
\hline TUA & 5'-TATTCTCAGAGGCACACTCG-3' & 5'-AACGGCAGGCTCTTGAACTA-3' \\
\hline
\end{tabular}

Table 5. Primers used for cloning the reference gene open reading frames.

with three replicates, each comprising five seedlings. All collected leaf samples were immediately frozen in liquid nitrogen and stored at $-80^{\circ} \mathrm{C}$ until analyzed.

RNA extraction and cDNA synthesis. Total RNA was extracted from the frozen leaf samples with the MiniBEST Plant RNA Extration Kit (TaKaRa, Dalian, China). The NanoDrop ND1000 spectrophotometer (Thermo Scientific, Wilmington, DE, USA) was used to calculate the RNA concentration and assess purity. The RNA samples with a 260/280 nm absorbance ratio of 1.8-2.0 were retained for further analyses. The RNA integrity was evaluated by $1 \%$ agarose gel electrophoresis. The PrimeScript II First Strand cDNA Synthesis Kit $(\mathrm{TaKaRa})$ was used to synthesize cDNA.

Reference gene isolation and sequence analysis. Transcripts for five potential reference genes $(A C T$, $T U A, T U B, E F-1 \alpha$, and GAPDH) were identified following a search of an established luffa transcriptome database. Complete open reading frames (ORFs) were obtained for all sequences. Gene-specific primers were designed to clone and verify the ORF sequences of the five genes (Table 5). The PCR amplification was completed in a reaction solution consisting of $1 \mu \mathrm{L} \mathrm{cDNA}(100 \mathrm{ng}), 1 \mu \mathrm{L} 0.4 \mu \mathrm{M}$ forward primer, $1 \mu \mathrm{L} 0.4 \mu \mathrm{M}$ reverse primer, $0.5 \mu \mathrm{L}$

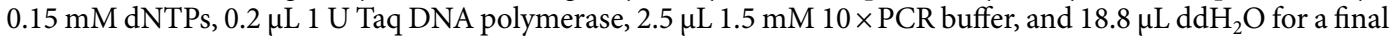
volume of $25 \mu \mathrm{L}$. The PCR program was as follows: $94^{\circ} \mathrm{C}$ for $3 \mathrm{~min} ; 35 \mathrm{cycles}$ of $94^{\circ} \mathrm{C}$ for $30 \mathrm{~s}, 54^{\circ} \mathrm{C}$ for $30 \mathrm{~s}$, and $72{ }^{\circ} \mathrm{C}$ for $90 \mathrm{~s} ; 72{ }^{\circ} \mathrm{C}$ for $7 \mathrm{~min}$. The PCR products were analyzed by $1 \%$ agarose gel electrophoresis. They were then purified and inserted into the pMD-19T vector and sequenced. The homology between the five potential reference gene nucleotide sequences and known sequences was determined with the NCBI BLAST algorithm.

Reference gene selection and primer design. The seven genes initially selected as candidate reference genes included the $A C T, T U A, T U B, E F-1 \alpha$, and GAPDH genes as well as two previously cloned reference genes, $U B Q^{16}$ and $18 S^{15}$. Details regarding these genes are provided in Table 1. All qRT-PCR primers were designed with the Primer 5.0 software. The specificity of each primer pair was evaluated by $1 \%$ agarose gel electrophoresis and a melting curve analysis. The PCR amplification efficiency (E) and correlation coefficient $\left(\mathrm{R}^{2}\right)$ for each qRTPCR primer pair were calculated with a fivefold cDNA dilution series ${ }^{52}$.

qRT-PCR analysis. A qRT-PCR assay was completed with SYBR Premix Ex Taq (TaKaRa) and the QuantStudio 7 Flex Real-Time PCR System (Applied Biosystems, USA). The reaction solution consisted of $10 \mu \mathrm{L}$ SYBR Green PCR Master Mix (TaKaRa), $2 \mu \mathrm{L}$ cDNA (100 ng), $0.8 \mu \mathrm{L} 10 \mu \mathrm{M}$ forward primer, $0.8 \mu \mathrm{L} 10 \mu \mathrm{M}$ reverse primer, $0.4 \mu \mathrm{L}$ ROX Reference Dye II, and $6 \mu \mathrm{L} \mathrm{ddH}_{2} \mathrm{O}$ for a final volume of $20 \mu \mathrm{L}$. The amplification conditions were as follows: $95^{\circ} \mathrm{C}$ for $30 \mathrm{~s} ; 40$ cycles of $95^{\circ} \mathrm{C}$ for $5 \mathrm{~s}, 60^{\circ} \mathrm{C}$ for $34 \mathrm{~s}$, and $72^{\circ} \mathrm{C}$ for $10 \mathrm{~s}$, followed by a melting curve analysis from 65 to $95^{\circ} \mathrm{C}$. A blank control lacking a template was also analyzed. The gene expression levels for each sample were determined based on three replicates.

Data analysis. The cycle threshold (Ct) value was recorded for each qRT-PCR analysis of gene expression. Box plots were drawn to visualize the reference gene expression levels and variations. The geNorm, NormFinder, BestKeeper, and RefFinder algorithms were used to assess the expression stability of selected genes. Specifically, geNorm calculates the expression stability value $(\mathrm{M})$ and pairwise variation $(\mathrm{V})$, and the most stably expressed gene is the one with the lowest $\mathrm{M}$ value. Moreover, geNorm determines the optimal number of reference genes according to the relative value $\mathrm{V}_{\mathrm{n}} / \mathrm{V}_{\mathrm{n}+1}$. NormFinder calculates a stability value (SV) for each gene based on the variance analysis, and the gene with the lowest SV is identified as the most stably expressed gene. For both algorithms, the Ct values should first be transformed by $2^{-\Delta \mathrm{Ct}}$. BestKeeper mainly determines the stability of reference gene expression based on the standard deviation (SD), Pearson correlation coefficient (r), and the coefficient of variation $(\mathrm{CV})$ of the $\mathrm{Ct}$ data for all reference genes. The most stably expressed gene is the one with the lowest SD and CV values. Finally, the reference genes were ranked based on the geometric mean (GM) values calculated with RefFinder (http://www.leonxie.com/referencegene.php).

Validation of reference genes. To confirm the reliability of the reference genes, the expression profiles of $\mathrm{Cu} / \mathrm{Zn}$-SOD gene were determined and normalized against the data for the two most stable and the least stable reference genes ${ }^{22}$. The qRT-PCR amplification conditions were as described above and the primer pairs are listed in Table 1 . The relative expression data were calculated with the $2^{-\Delta \Delta \mathrm{Ct}} \operatorname{method}^{53}$. Statistical analyses were performed with the SPSS 18 program. 
Ethics approval and consent to participate. Not applicable.

Consent for publication. All authors have consented for publication.

\section{Data availability}

The datasets supporting the conclusions and description of a complete protocol are included within the article.

Received: 15 September 2020; Accepted: 6 January 2021

Published online: 04 February 2021

\section{References}

1. Huggett, J., Dheda, K., Bustin, S. \& Zumla, A. Real-time RT-PCR normalisation; strategies and considerations. Genes Immun. 6, 279-284 (2005).

2. Radonić, A. et al. Guideline to reference gene selection for quantitative real-time PCR. Biochem. Biophys. Res. Commun. 313, 856-862 (2004).

3. Ye, J. et al. Selection of suitable reference genes for qRT-PCR normalisation under different experimental conditions in Eucommia ulmoides Oliv. Sci. Rep. 8, 15043 (2018).

4. Sun, Z. Y., Deng, J., Wu, H. Z., Wang, Q. Y. \& Zhang, Y. X. Selection of stable reference genes for Real-Time quantitative PCR analysis in Edwardsiella tarda. J. Microbiol. Biotechnol. 27, 112-121 (2017).

5. Tan, S. C. et al. Identification of optimal reference genes for normalization of RT-qPCR data in cancerous and non-cancerous tissues of human uterine cervix. Cancer Invest. 35, 163-173 (2017).

6. Suzuki, T., Higgins, P. J. \& Crawford, D. R. Control selection for RNA quantitation. Biotechniques 29, 332-337 (2000)

7. Bustin, S. A. Quantification of mRNA using real-time reverse transcription PCR (RT-PCR): trends and problems. J. Mol. Endocrinol. 29, 23-29 (2002).

8. Gantasala, N. P. et al. Selection and validation of reference genes for quantitative gene expression studies by real-time PCR in eggplant (Solanum melongena L.). BMC Res. Notes 6, 312 (2013).

9. Lopez-Pardo, R., de Galarreta, J. I. R. \& Ritter, E. Selection of housekeeping genes for qRT-PCR analysis in potato tubers under cold stress. Mol. Breed. 31, 39-45 (2013).

10. Li, M. Y., Wang, F. \& Jiang, Q. Validation and comparison of reference genes for $q$ PCR normalization of celery (Apium graveolens) at different development stages. Front. Plant Sci. 7, 313 (2016).

11. Ma, R., Xu, S., Zhao, Y. C., Xia, B. \& Wang, R. Selection and validation of appropriate reference genes for quantitative real-time PCR analysis of gene expression in Lycoris aurea. Front. Plant Sci. 7, 536 (2016).

12. Gutierrez, L. et al. The lack of a systematic validation of reference genes: a serious pitfall undervalued in reverse transcriptionpolymerase chain reaction (RT-PCR) analysis in plants. Plant Biotechnol. J. 6, 609-618 (2008).

13. Oboh, I. O. \& Aluyor, E. O. Luffa cylindrica-an emerging cash crop. Afr. J. Agric. Res. 4, 684-688 (2009).

14. Asif, M. \& Kamran, A. Crop stress and its management: perspectives and strategies. Crop Sci. 52, 1968-1969 (2012).

15. Zhu, H. S. et al. Cloning of $18 \mathrm{~S}$ rRNA gene from Luffa cylindrical and its application as an internal standard. Acta Agric. Nucl. Sin. 30, 35-41 (2016).

16. Chen, M. D., Wang, B., Zhu, H. S. \& Wen, Q. F. Cloning and expression analysis of polyubiquitin gene (LcUBQ) in Luffa cylindrica. Chin. J. Cell Biol. 40, 89-98 (2018).

17. Gibson, U. E., Heid, C. A. \& Williams, P. M. A novel method for real time quantitative RT-PCR. Genome Res. 6, 995-1001 (1996).

18. Bustin, S. A. Absolute quantification of mRNA using real-time reverse transcription polymerase chain reaction assays. J. Mol. Endocrinol. 25, 169-193 (2000).

19. Die, J. V., Román, B., Nadal, S. \& González-Verdejo, C. I. Evaluation of candidate reference genes for expression studies in Pisum sativum under different experimental conditions. Planta 232, 145-153 (2010).

20. Kong, Q. S. et al. Screening suitable reference genes for normalization in reverse transcription quantitative Real-Time PCR analysis in melon. PLoS ONE 9, e87197 (2014).

21. Li, H. B. et al. Screening potential reference genes for quantitative real-time PCR analysis in the oriental armyworm, Mythimna separata. PLoS ONE 13, e0195096 (2018).

22. Deng, L. T. et al. Screening reliable reference genes for RT-qPCR analysis of gene expression in Moringa oleifera. PLoS ONE 11, e0159458 (2016)

23. Reid, K. E., Olsson, N., Schlosser, J., Peng, F. \& Lund, S. T. An optimized grapevine RNA isolation procedure and statistical determination of reference genes for real-time RT-PCR during berry development. BMC Plant Biol. 6, 27 (2006).

24. Long, X. Y. et al. Genome-wide identification and evaluation of novel internal control genes for Q-PCR based transcript normalization in wheat. Plant Mol. Biol. 74, 307-311 (2010).

25. Mascia, T., Santovito, E., Gallitelli, D. \& Cillo, F. Evaluation of reference genes for quantitative reverse transcription polymerase chain reaction normalization in infected tomato plants. Mol. Plant Pathol. 11, 805-816 (2010).

26. Gong, L. et al. $L b C M L 38$ and $L b R H 52$, two reference genes derived from RNA-Seq data suitable for assessing gene expression in Lycium barbarum L. Sci. Rep. 6, 37031 (2016).

27. Liu, Q. X. et al. Reference gene selection for quantitative Real-Time reverse-transcriptase PCR in annual ryegrass (Lolium multiflorum) subjected to various abiotic stresses. Molecules 23, 172 (2018).

28. Tang, X., Zhang, N., Si, H. J. \& Calderón-Urrea, A. Selection and validation of reference genes for RT-qPCR analysis in potato under abiotic stress. Plant Methods 13, 85 (2017).

29. Stephan, L., Tilmes, V. \& Hülskamp, M. Selection and validation of reference genes for quantitative Real-Time PCR in Arabis alpina. PLoS ONE 14, e0211172 (2019).

30. Migocka, M. \& Papierniak, A. Identification of suitable reference genes for studying gene expression in cucumber plants subjected to abiotic stress and growth regulators. Mol. Breed. 28, 343-357 (2011).

31. Warzybok, A. \& Migocka, M. Reliable reference genes for normalization of gene expression in cucumber grown under different nitrogen nutrition. PLoS ONE 8, e72887 (2013).

32. Wan, H. J. et al. Selection of appropriate reference genes for gene expression studies by quantitative real-time polymerase chain reaction in cucumber. Anal. Biochem. 399, 257-261 (2010).

33. Obrero, A. et al. Selection of reference genes for gene expression studies in zucchini (Cucurbita pepo) using qPCR. J. Agric. Food Chem. 59, 5402-5411 (2011)

34. Ye, X. R. et al. Screening and evaluation of reference genes for RT-qPCR in wax gourd (Benincasa hispida Cogn.). Acta Agric. Nucl. Sin. 33, 473-481 (2019).

35. Jin, Y. et al. Identification of reliable reference genes for $\mathrm{qRT}-\mathrm{PCR}$ in the ephemeral plant Arabidopsis pumila based on full-length transcriptome data. Sci. Rep. 9, 8408 (2019). 
36. Auler, P. A. et al. Selection of candidate reference genes and validation for real-time PCR studies in rice plants exposed to low temperatures. Genet. Mol. Res. 16, 1-15 (2017).

37. Jia, D. H. et al. Validation of reference genes for quantitative gene expression analysis in Auricularia cornea. J. Microbiol. Methods 163, 105658 (2019).

38. Kiarash, J. G. et al. Selection and validation of reference genes for normalization of qRT-PCR gene expression in wheat (Triticum durum L.) under drought and salt stresses. J. Genet. 97, 1433-1444 (2018).

39. Cheng, H., Kun, W. P., Liu, D. S., Su, Y. Q. \& He, Q. W. Molecular cloning and expression analysis of CmMlo1 in melon. Mol. Biol. Rep. 39, 1903-1907 (2012).

40. Shan, W. Y. et al. Antisense suppression of alcohol acetyltransferase gene in ripening melon fruit alters volatile composition. Sci. Hortic. 139, 96-101 (2012).

41. Wei, S., Wang, L., Zhang, Y. \& Huang, D. Identification of early response genes to salt stress in roots of melon (Cucumis melo L.) seedlings. Mol. Biol. Rep. 40, 2915-2926 (2013).

42. Xu, M. et al. Reference gene selection for quantitative real-time polymerase chain reaction in Populus. Anal. Biochem. 408, 337-339 (2011).

43. Yu, Y. T. et al. Selection of reference genes for qPCR analyses of gene expression in ramie leaves and roots across eleven abiotic/ biotic treatments. Sci. Rep. 9, 20004 (2019).

44. Zhou, L., Niu, J. \& Quan, S. Identification of appropriate reference genes for RT-qPCR analysis in Juglans regia L. PLoS ONE 13, e0209424 (2018).

45. Zheng, T. et al. Reference gene selection for qRT-PCR analysis of flower development in Lagerstroemia indica and L. speciosa. PLoS ONE 13, e0195004 (2018).

46. Wan, D. et al. Selection of reference genes for qRT-PCR analysis of gene expression in Stipa grandis during environmental stresses. PLoS ONE 12, e0169465 (2017).

47. Mhamdi, A. et al. Catalase function in plants: a focus on Arabidopsis mutants as stress-mimic models. J. Exp. Bot. 61, 4197-4220 (2010).

48. Cui, L. J. et al. Molecular cloning and expression analysis of a Cu/ZnSOD gene (BcCSD1) from Brassica campestris ssp. chinensis. Food Chem. 186, 306-311 (2015).

49. Guan, Q. J. et al. Tolerance analysis of chloroplast OsCu/Zn-SOD overexpressing rice under $\mathrm{NaCl}$ and $\mathrm{NaHCO}_{3}$ stress. PLoS ONE 12, $\mathrm{e} 0186052$ (2017).

50. Abu-Romman, S. \& Shatnawi, M. Isolation and expression analysis of chloroplastic copper/zinc superoxide dismutase gene in barley. S. Afr. J. Bot. 77, 328-334 (2011).

51. de Jonge, H. J. et al. Evidence based selection of housekeeping genes. PLoS ONE 2, e898 (2007).

52. Radonic, A. et al. Guideline to reference gene selection for quantitative real-time PCR. Biochem. Biophys. Res. Commun. 313, 856-862 (2004).

53. Livak, K. J. \& Schmittgen, T. D. Analysis of relative gene expression data using real-time quantitative PCR and the $2^{-\Delta \Delta C t}$ method. Methods 25, 402-408 (2001).

\title{
Acknowledgements
}

This work was supported by the Fujian Natural Science Foundation Project (Grant No. 2019J01112), Fujian Provincial Public Research Institute of Fundamental Research (Grant No. 2019R1031-7), Fujian Academy of Agricultural Sciences Vegetable Science and Technology Innovation Team (Grant No. STIT2017-1-2), National Vegetable Industry Technology System Fuzhou Comprehensive Test Station (Grant No. CARS-23-G-53), Central Government Guiding Local Science and Technology Development Special Project (2018L005) and Fujian Major Science and Technology Project (2018NZ0002-3). We thank Liwen Bianji, Edanz Editing China (www.liwenbianj i.cn/ac) for editing the English text of a draft of this manuscript.

\section{Author contributions}

M.D.C., H.S.Z. and Q.F.W. designed the experiments. M.D.C., B.W., Y.P.L. and X.R.Y. performed the experiments and analyzed the data. M.D.C., J.T.L., and M.J.Z. wrote the manuscript. All authors read and approved the final manuscript.

\section{Competing interests}

The authors declare no competing interests.

\section{Additional information}

Supplementary Information The online version contains supplementary material available at https://doi. org/10.1038/s41598-021-81524-w.

Correspondence and requests for materials should be addressed to H.Z. or Q.W.

Reprints and permissions information is available at www.nature.com/reprints.

Publisher's note Springer Nature remains neutral with regard to jurisdictional claims in published maps and institutional affiliations.

\begin{abstract}
Open Access This article is licensed under a Creative Commons Attribution 4.0 International cc) License, which permits use, sharing, adaptation, distribution and reproduction in any medium or
format, as long as you give appropriate credit to the original author(s) and the source, provide a link to the Creative Commons licence, and indicate if changes were made. The images or other third party material in this article are included in the article's Creative Commons licence, unless indicated otherwise in a credit line to the material. If material is not included in the article's Creative Commons licence and your intended use is not permitted by statutory regulation or exceeds the permitted use, you will need to obtain permission directly from the copyright holder. To view a copy of this licence, visit http://creativecommons.org/licenses/by/4.0/.
\end{abstract}

(C) The Author(s) 2021 